\title{
The Effect of Regulatory Intervention in Two-Sided Markets: An Assessment of Interchange-Fee Capping in Australia
}

\author{
HOWARD CHANG, DAVID S. EVANS, AND DANIEL D. GARCIA SWARTZ *
}

LECG, LLC

\begin{abstract}
We examine the impact to date of the Reserve Bank of Australia's decision to reduce interchange fees on credit cards in Australia by almost half. We find that, in the short run, issuers have recovered between 30 and 40 percent of the loss of interchange fees. Merchants have benefited from lower fees but it is questionable whether those benefits have been substantially passed on to their customers. The per-transaction price at the point of sale has not changed significantly and there is relatively little evidence thus far that the intervention has affected the volume of card transactions in Australia.
\end{abstract}

\section{Introduction}

This article examines the effect of a significant regulatory-mandated alteration in pricing policy in a two-sided industry. ${ }^{1}$ In doing so it provides empirical evidence that is helpful for understanding how two-sided industries work. It also sheds light on the interaction between the design of regulatory interventions and the pricing policies in two-sided industries.

In 2003, the Reserve Bank of Australia (RBA) mandated a reduction in the "interchange fee". In the context of a credit card transaction, this is the fee that the bank that acquires the receivable from the merchant pays to the bank that issued the card to the consumer. Three associations of banks in Australia had centrally set the interchange fee at around 0.95 percent of the transaction value. The RBA imposed cost-based regulation that resulted in a reduction of the interchange fee to around 0.55 percent. Absent any other

\footnotetext{
* Contact author. Howard Chang, LECG, LLC, 33 West Monroe, Suite 2300, Chicago, IL USA 60603. howard chang@lecg.com A previous version of this paper was presented at the "Antitrust Activity in CardBased Payment Systems: Causes and Consequences" conference held by the Federal Reserve Bank of New York on September 15-16, 2005. We appreciate the helpful comments of Tom Brown, Richard Epstein, Joseph Farrell, Timothy Muris, and Richard Schmalensee. We also appreciate the superb research help of Nadia Hussaini, Nese Nasif, and Sannu Shrestha, and financial support from Visa U.S.A. We retain the rights to all errors.

${ }^{1}$ See Rochet and Tirole (2003) for the seminal work on two-sided markets, and Evans and Schmalensee (2005c) for a review of the industrial organization of two-sided markets.
} 
adjustment, this 0.40 percentage-point reduction in interchange fees eliminated roughly AU $\$ 490$ million in revenues that banks would have received from these fees in $2004 .^{2}$

The credit-card industry is often cited as a classic two-sided product: it intermediates the transactions between merchants and cardholders. ${ }^{3}$ This massive regulatory intervention therefore provides a natural experiment, almost, for assessing how an alteration in the price on one side of a two-sided industry affects the other interdependent parts of the system. In addition, more so than many interventions, the RBA's mandated reduction in interchange fees is so substantial that it provides the hope that one can determine empirically whether the intervention achieved its objectives.

After a number of studies, the RBA concluded that interchange fees that were "too high" helped sustain card transaction prices (to consumers) that were "too low" from a social perspective. This resulted in the overuse of cards relative to other, allegedly cheaper, payment instruments. The main objective of the regulation, therefore, was to raise the price of credit transactions to cardholders and thereby reduce the use of cards. Of course, at the time of this writing this experiment has only lasted for less than two years - it is possible at this time to assess only short-run effects.

In Section 2 we provide some background on the Australian credit-card industry. Then we turn in Section 3 to a summary of the RBA's theory for regulatory intervention. Section 4 provides a brief discussion of the possible effects of this intervention based on economic theory. Section 5 presents our empirical analysis and Section 6 lays out its implications for the RBA's intervention. We end with conclusions and suggestions for further research in Section 7.

\section{The Australian credit card industry}

The geography and demographics of Australia have shaped the card industry and retail sector that are the focus of this paper. Australia had a population of roughly 19 million people in $2001 .^{4}$ About 65 percent of its population lived in 8 coastal cities that year. ${ }^{5}$ The distance between cities is great and much of the country has a very low population density.

Credit cards were first issued in Australia in 1974. Bankcard, a product that arose from the collaboration among Australian banks, was the first credit card issued in the country by 1977 it was accepted nationally. As in the rest of the world, MasterCard and Visa marketed their products in Australia as associations of banks. Their cards started gaining traction in the mid-1980s. American Express and Diners Club came to Australia as proprietary systems, while MasterCard and Visa have had members that issue cards to consumers (issuers) and sign up and service merchants to take association cards (acquirers). American Express and Diners Club have acquired merchants on their own. ${ }^{6}$

\footnotetext{
${ }^{2}$ The reduction was 0.40 percent. According to the RBA, total nominal purchase volume on credit and charge cards was about $\$ 147$ billion in 2004. Furthermore, Bankcard, Visa and MC accounted for about 83.8 percent of total volume in that year, that is they accounted for about $\$ 123$ billion. See RBA (2005c).

${ }^{3}$ See Baxter (1983), Rochet and Tirole (2002, 2003) and Schmalensee (2002).

${ }^{4}$ See Australian Bureau of Statistics (2001).

${ }^{5}$ See Australian Bureau of Statistics (2003).

${ }^{6}$ See Reserve Bank of Australia (RBA) and Australian Competition and Consumer Commission (ACCC) (2000, p.15). For a general introduction to payment cards see Evans and Schmalensee (2005a). American Express reached an agreement with AMP in 1998 to issue cards in Australia. More prominently, as we
} 
Banking in Australia is relatively concentrated. There are 53 banking groups in total. ${ }^{7}$ The four leading banks are National Australia Bank, Australia \& N.Z. Banking Group, Westpac Banking Corp., and Commonwealth Bank Of Australia, which collectively account for 66 percent of total deposits. ${ }^{8}$ Furthermore, credit card issuing and acquiring are highly concentrated. In 1999, the cards that the four major banks issued accounted for about 85 percent of all credit card transactions; these same banks accounted for about 93 percent of credit card transactions acquired. ${ }^{9}$

Consider the situation when a consumer presents her card for payment at a merchant. When the entity that serves the cardholder is the same as the entity that serves the merchant, the transaction is "on-us". While the entity may have transfer pricing and other matters to deal with between its issuing and acquiring "divisions", the transaction is internal to the firm. That is always the case for proprietary systems that integrate acquiring and issuing and sometimes the case for association-based systems. When the cardholder and merchant entities differ, they have to have some agreement as to who bears various risks and how the costs and benefits of the transaction get divided up. In principle that could happen through either bilateral negotiations between them, or a fee and other contract terms that are set centrally by the association or regulators, or an industry standard that substitutes for an agreement. ${ }^{10}$ In Australia, Bankcard, MasterCard, and Visa adopted a multilaterally set fee. ${ }^{11}$ As mentioned, that fee was slightly less than one percent of the transaction amount before the regulatory intervention. ${ }^{12}$

The interchange fee is a cost to the acquirer and is passed on to the merchant in whole or in part. The merchant discount is the percent of the transaction that the merchant pays to the acquirer. The merchant service fees for the four card brands were the following just before regulation: for Amex, 2.57 percent; for Diners Club, 2.35 percent; and for Visa and MasterCard, 1.41 percent. $^{13}$

As of 2001, the number of merchants accepting MasterCard, Bankcard, and Visa cards was about twice as large as the number of merchant accepting American Express. The merchant base for Diners Club was apparently smaller than for American Express. ${ }^{14}$ At

discuss below, major Australian banks have signed up with American Express and Diners Club since the RBA's interchange fee regulation.

${ }^{7}$ Excluding subsidiaries. Source: RBA, at

http://www.rba.gov.au/FinancialSystemStability/FinancialInstitutionsInAustralia/the main types_of financi al_institutions_in_aus.html

${ }^{8}$ See Australian Prudential Regulation Authority (2005). The APRA calculates total deposits as the sum of transaction deposit accounts, non-transaction deposit accounts, and certificates of deposit. It excludes intragroup deposits.

${ }^{9}$ See RBA and ACCC (2000, p.17).

${ }^{10}$ See Evans and Schmalensee (2005b) for further discussion on interchange fee setting.

${ }^{11}$ See, for example, RBA (2001, p.14).

12 According to the Joint Study, the average interchange fee that issuers received in 1999 was 0.95 percent. Strictly speaking, interchange fees differed for Visa and MasterCard depending on whether the transaction was carried out with the "card present" or not. As of the end of 2001, the electronic (card-present) rate for Visa and MasterCard was 0.8 percent and the rate for all other transactions was 1.2 percent. The Bankcard banks charged 1.2 percent on all transactions, although apparently they had agreed to introduce an electronic rate of 0.8 percent toward the end of 2001. See RBA (2001, pp.14-15).

${ }^{13}$ See RBA, Merchant Fees for Credit and Charge Cards, available at http://www.rba.gov.au/Statistics/Bulletin/C03hist.xls

${ }^{14}$ See RBA (2001, p.119). 
this time there were roughly 13 million credit cards in use by consumers in Australia. ${ }^{15}$ Table 1 shows the shares of each brand.

\begin{tabular}{|c|c|}
\hline Brand & Percent of cards on issue \\
\hline Visa & 51.4 \\
MasterCard & 22.7 \\
Bankcard & 19.2 \\
American Express charge & 2.8 \\
American Express credit & 2.2 \\
Diners Club & 1.7 \\
\hline
\end{tabular}

Table 1: Shares of major credit and charge card brands, percent of cards on issue, 1999/2000

Source: RBA and ACCC (2000, p.15).

\section{$3 \quad$ Regulation and Its rationale}

The RBA and the Australian Competition and Consumer Commission (ACCC) published a "Joint Study" of payment systems in October 2000. ${ }^{16}$ The Joint Study found that credit card interchange fees encouraged the provision of credit card services at negative prices to consumers and this fostered the use of credit cards instead of PIN debit cards, which the Joint Study believed to be a less costly instrument. ${ }^{17}$

In December 2001, the RBA published a "Consultation Document", outlining the need for regulation of the payment system. According to the Consultation Document, the pricing of credit card services was sending "consumers a quite misleading signal about the cost to the community of different payment instruments". ${ }^{18}$ The Consultation Document proposed regulating the credit card schemes using "an objective, transparent and cost-based methodology for determining interchange fees". 19

The Joint Study and the Consultation Document identified three aspects of credit card scheme rules that allegedly impeded the efficiency of the overall payments system - the collective setting of interchange fees, the "no surcharge" rule, and certain restrictions on entry to the schemes. These were the key issues addressed in the regulations introduced in

\footnotetext{
${ }^{15}$ See RBA and ACCC (2000, p.15).

${ }^{16}$ See RBA and ACCC (2000).

${ }^{17}$ The debit cards the RBA views as less costly are the EFTPOS PIN debit cards, not the Visa debit cards that are also offered. MasterCard does not offer a debit card in Australia.

${ }^{18}$ See RBA (2001, p.vi).

19 ibid, p.116.
} 
the years that followed. ${ }^{20}$ After designating the credit-card schemes as payment systems under its regulation, the RBA undertook a process of consultation and analysis to determine whether the RBA's intervention would be in the public interest. The RBA published final standards regarding interchange fees and the no-surcharge rule in August 2002 and on the access regime in February $2004 .^{21}$

It is outside the purview of this paper to discuss the reasoning and evidence that the RBA relied on in any detail. We provide a quick summary. When customers make a purchase with their credit cards at the point of sale, the acquirer passes the interchange fee costs on to the merchant. With the no-surcharge rule, the merchant cannot effectively charge cardholders for any additional costs it incurs in accepting credit-card payments. As a result the cardholder does not have the correct incentives to use the most efficient form of payment. Prices faced by consumers do not fully reflect social costs and there is a resulting distortion.

The RBA buttressed this argument with evidence suggesting that credit cards are more costly than debit cards. Furthermore, the merchant passes the cost of payment methods onto its customers just like it passes all costs on. Since it cannot charge cardholders specifically for their use of cards, it passes the interchange fee - part of the merchant discount - on to all customers. The issuer, in turn, receives interchange fees as revenues. To increase this source of revenue it has incentives to encourage consumers to use their cards and it does so by providing rewards and other inducements. As a result, cardholders face negative prices for using cards and the price of using cards at the point of sale is lower than their cost. This results in a misallocation of resources (the overuse of cards and underuse of allegedly more efficient forms of payment) and a perverse distributional effect (people who do not use cards at the point of sale subsidize cardholders). ${ }^{22}$

In September 2002, MasterCard International and Visa International challenged the RBA's decision in the Federal Court on procedural and jurisdictional grounds. The Court rejected the challenge in September 2003, finding against MasterCard and Visa. The nosurcharge standard came into effect on January 1, 2003. The standard on interchange fees came into effect on July 1, 2003. The Bank required the credit card schemes to publish and put in force the new interchange fees by October 31, 2003. For all practical purposes, in November 2003 interchange fees declined from an average of around 0.95 percent to around 0.55 percent. $^{23}$ The timeline is shown in Table 2 .

\footnotetext{
${ }^{20}$ See RBA (2004, p.7).

${ }^{21}$ ibid, p.7.

${ }^{22}$ We do not dispute this analysis for the purpose of this article; see Evans and Schmalensee (2005b) and Rochet (2005) for some comments. Our focus here is only on whether the RBA intervention achieved its goals.

${ }^{23}$ See RBA (2004, pp.8-9).
} 


\begin{tabular}{|c|c|}
\hline Date & Ev \\
\hline October 2000 & Publication of the Joint Study \\
\hline April 2001 & $\begin{array}{l}\text { Designation of Visa, MC, and Bankcard as payment systems subject } \\
\text { to regulation }\end{array}$ \\
\hline December 2001 & Publication of the Consultation Document \\
\hline August 2002 & $\begin{array}{l}\text { Publication of final standards regarding no-surcharge and interchange } \\
\text { fees }\end{array}$ \\
\hline September 2002 & Visa and $\mathrm{MC}$ challenge standards in court \\
\hline January 2003 & No-surcharge standard comes into effect \\
\hline July 2003 & Interchange standard comes into effect \\
\hline September 2003 & Court rejects the Visa-MC challenge of the standards \\
\hline October 2003 & New interchange fees are implemented \\
\hline February 2004 & Publication of final standard on entry \\
\hline
\end{tabular}

Table 2: Timeline of RBA investigation and regulation

Source:RBA and ACCC (2000), RBA (2001), and RBA (2004).

\section{Some theoretical considerations on the effect of the intervention}

The effect of this regulation depends on the manner in which prices are determined in this industry and the market structure of the participants. The theory of two-sided markets provides a framework for considering these issues. Businesses in two-sided markets determine price levels and price structures recognizing that the demands of their two customer groups are interdependent (Rochet and Tirole, 2003). Two-part tariffs are common in recognition of the fact that many two-sided bases involve membership and use (Evans and Schmalensee, 2005c). In the case of credit cards, card systems typically have a nominal or zero membership fee for merchants (although merchants do have to buy equipment), a membership fee for cardholders that is greater than or equal to zero (positive fees include an annual fee and various service fees), a usage fee for merchants which is usually a percent of the total transaction, and a usage fee for cardholders that is usually less than zero (float for several weeks, reward miles and other perquisites that are usually a function of volume). Credit cards bundle a transaction and finance feature; cardholders pay a finance fee on the amount they choose not to pay when their bill is due.

Average prices for reward cards with a grace period, as well as merchant fees, as of 2001, are shown in Table 3. 


\section{CARDHOLDER FEES}

Annual fee - standard cards (AU\$)

Annual fee - gold cards (AU\$)

Late payment fee (AU\$)

Over-limit fee (AU\$)

6

\section{MERCHANT FEES $(*)$}

Merchant service fee - Visa, MasterCard, and Bankcard

Merchant service fee - American Express
1.41 percent

2.55 percent

\section{Table 3: Cardholder and merchant fees, 2001}

Sources: RBA (2005a). (*) The merchant service fees are from March 2003. The source is Merchant Fees for Credit and Charge Cards, available at http://www.rba.gov.au/Statistics/Bulletin/C03hist.xls

The regulatory intervention did not affect any of these prices directly. However, by reducing the interchange fee by almost half the intervention reduced significantly a major source of revenue to bankcard issuers. This naturally would be expected to lead them to reequilibrate their prices. While that seems certain as a matter of economic theory, two issues remain open - the extent to which they will adjust fixed versus variable prices, and the extent to which the reduction in prices on one side will get passed on to the other side. There is, to our knowledge, no off-the-shelf theoretical guidance on how a binding ceiling on one of the four possible prices will affect the other three prices in a two-sided market. As in other markets, the extent to which the loss in revenue from merchants will get passed on to cardholders depends on the degree of competition among card issuers. Given that card issuing in Australia is relatively concentrated we would not expect full pass through, at least in the short run. ${ }^{24}$

It is well known that in perfectly competitive markets there is full pass through of cost changes. A $\$ 1$ decrease in marginal costs will lead to a $\$ 1$ decrease in price. With imperfectly competitive markets the extent of pass through depends as a theoretical matter on the shape of the demand curve. ${ }^{25}$ With linear demand curves there is less than a 100 percent pass through of costs to final consumers. For the very small cost decreases involved here it is reasonable to assume linear demand (since the curvature of demand can

\footnotetext{
${ }^{24}$ See below for a discussion of the theoretical and empirical evidence on the degree of pass through.

${ }^{25}$ Cotterill (1998) provides a summary of the relationship between market structure and cost pass through. If the industry is perfectly competitive and firms maximize profits, then the rate of pass through is 100 percent, no matter what the value of the market elasticity of demand is. If the industry is a monopoly, demand for its product is linear, and the monopolist maximizes profits, the pass through rate is less than 100 percent. More specifically, for a monopolist that faces a linear demand curve, the pass through rate is 50 percent. See, for example, Bulow and Pfleiderer (1983). If, on the other hand, a monopolist faces a constant-elasticity demand curve over the relevant range it is possible that pass through could be greater than 100 percent. Assuming a linear demand curve is reasonable for small changes in costs but not necessarily for larger changes in cost.
} 
be ignored for such small changes) and therefore to expect less than 100 percent passthrough as a matter of theory. Empirical studies tend to find less than 100 percent pass through more frequently than greater than 100 percent pass through; the greater-than-100percent pass through rate appears to happen in the empirical tax incidence literature and the empirical effects are confounded with the sticky-price issue discussed below. ${ }^{26}$ Thus, we would expect less than 100 percent pass-through as an empirical matter.

There is a further consideration, from a theoretical perspective, on how the regulatory intervention would affect final good prices. It is well known that many prices are sticky in the short run (Stigler and Kindahl, 1970; and Carlton, 1986). Of particular interest in our case is the finding that prices tend to rise faster than they fall. A number of studies in the 1990s found that retail prices respond faster to input price increases than to input price decreases (Karrenbrock, 1991; Newmark and Sharpe, 1992; Borenstein, Cameron, and Gilbert, 1997; and Jackson, 1997). More recently, Peltzman (2000) confirmed this finding with a large sample of consumer and producer goods. This is especially important for considering short-run versus long-run effects of the intervention.

The credit-card acquiring business in Australia is highly concentrated. The four major banks accounted for 93 percent of credit card transactions acquired in $1999 .{ }^{27}$ In contrast, the share of the four major acquirers in the United States is around 41 percent. ${ }^{28}$ As we note below, the RBA has reported that the reductions in the interchange fee appear to have been fully passed through to merchants. This is not surprising because, despite the relative concentration of acquirers, many merchants are large customers and can bargain effectively with acquirers. In addition, the acquirers are aware that their actions have been

\footnotetext{
${ }^{26}$ The empirical literature on pass through is fairly vast and covers a number of areas, including exchange rate and tax rate pass through to prices. The literature on pass through of exchange rate changes to domestic prices of traded goods finds that the median rate of pass through is roughly 50 percent for shipments to the US. See Goldberg and Knetter (1997). In the context of the proposed merger between Staples and Office Depot, Ashenfelter et al (1998) made a distinction between the firm-specific cost pass through rate and the industry-wide pass through rate - that is, the reaction of the firm's prices to changes in its own costs and to changes in costs common to all firms in the industry. They found that the firm-specific pass through rate for Staples was roughly 15 percent, whereas the industry wide pass through rate was around 57 percent. Furthermore, there is a literature focused on pass through of trade promotions to retail prices, which is a form of firm-specific pass through. There are a number of relevant studies in this area, including Chevalier and Curhan (1976), Walters (1989), Armstrong (1991), and Besanko, Dube, and Gupta (2005). Besanko et al (2005) analyze the degree of pass through of trade promotions using scanner data for eleven product categories at a Chicago supermarket chain. 8 out of 11 categories show pass through rates of less than 100 percent. At a more disaggregated level, only 165 products out of 1164 (about 14 percent) show pass through rates significantly larger than 100 percent. Besanko et al (2005) cite a study of trade promotions according to which retailers themselves said that they pass through roughly 62 percent of the promotion, use 24 percent to cover promotion costs, and keep the rest as profits. In the context of this literature, Blattberg et al (1985) suggest that, as an empirical matter, most products display pass through rates much smaller than 100 percent. Furthermore, Tyagi (1999) suggests that pass through rates of less than 100 percent should occur much more frequently than pass through rates of more than 100 percent, since the set of demand functional forms that imply less than 100 percent pass through is quite large. It seems to us that pass through rates of more than 100 percent are less frequent as an empirical matter than rates of less than 100 percent, and they tend to appear most often in the tax incidence literature. Poterba (1996), for example, is unable to reject the hypothesis of 100 percent pass through for the commodities he examines, but Besley and Rosen (1999) find greater than 100 percent pass through for several of the commodities in their sample. In line with our discussion of sticky prices below, note that empirical estimates of pass through mix pass through effects and sticky price effects.

${ }^{27}$ See RBA and ACCC (2000, pp.16-17).

${ }^{28}$ These calculations are based on data from HSN Consultants Inc. (2003).
} 
monitored closely by the RBA. As noted above, credit-issuing is also highly concentrated. We would therefore not anticipate full pass-through and, at least for the short-run, that is what we find.

Comprehensive government statistics on merchant concentration are not available for Australia. We have identified what data we could find from a range of sources. Many merchant categories appear to have significant levels of concentration. For example, within their respective categories, the top department store had a 71 percent share (and the top two had an 83 percent share) in $2003 ;{ }^{29}$ the top three supermarket and grocery stores had a 75.4 percent share in the late $1990 \mathrm{~s} ;{ }^{30}$ the top two mobile telephone operators had a 78 percent share in 2005; the top land-line telephone operator had a 75 percent share in $2005 ;^{31}$ and the top two airlines had an 83 percent share in $2005 .^{32}$

There are significant differences between the cardholder and merchant sides of the business that likely affect relative pass through rates to consumers on each side. The regulatory intervention caused issuers to experience a significant reduction in revenue (which could also be viewed as an increase in costs). That makes menu costs and other sources of sticky prices less binding. Moreover, it appears that it is quite easy for issuers to adjust prices by varying service and other card fees. For example, it seems that average annual fees on standard and gold cards changed (in a non-trivial manner) every year between 2000 and 2004. ${ }^{33}$ Lastly, linear demand is a more reasonable assumption for the merchants who experience a small relative cost decrease than for issuers who experience a relatively large cost increase (decreased interchange fees).

The main source of friction for issuers concerns the annual fee and other prices that issuers commit to in trying to persuade people to take their cards or to switch from another card. Cards are replaced about every three years; consequently that is the opportunity to institute or increase annual fees for current cardholders. For new solicitations it is easy to change fees whenever the solicitation goes out.

Merchants on the other hand experienced a relatively small reduction in cost. If fully passed through by acquirers, the interchange fee reduction amounts to less than half a percent of their selling price (and only on those transactions that take place on credit cards). The evidence on price rigidities, and particularly the one on asymmetric price responses cited above, makes one doubt that such a small cost reduction would affect final goods prices very quickly, even if there were extensive retail competition. We return to this point below.

\footnotetext{
${ }^{29}$ See Euromonitor International (2005a).

${ }^{30} \mathrm{See}$ http://www.aph.gov.au/senate/committee/retail_ctte/report/c04.htm. The Australian Bureau of Statistics reported the 75.4-percent figure, which was based on sales of all supermarkets and grocery stores, including the non-petrol sales of convenience stores at petrol stations. Furthermore, Euromonitor International (2005b) estimated that, in 2003, the size of the total grocery stores/food retailers/supermarkets sector was AU\$ 72.5 billion and the supermarket sub-sector represented 60.5 percent of that. The top two supermarkets had a combined market share (in the total sector) of 37.9 percent. Therefore, they had a combined market share in the supermarket sub-sector of 62.6 percent.

${ }^{31}$ See Maxwell (2005).

${ }^{32}$ See Bureau of Transportation Statistics (2000).

${ }^{33}$ See RBA (2005a).
} 


\section{$5 \quad$ Empirical analysis: Prices and quantities}

Although there was a sharp reduction in interchange fees on a particular date as a result of the RBA intervention, we cannot simply compare markets before and after this intervention. The credit-card industry learned over the course of several years that an intervention was increasingly likely. Furthermore, over time it developed a sense of the impact that the intervention would have. We thus begin by examining the time line a bit more carefully.

Although regulated interchange fees did not come into effect until the end of October 2003, there was anticipation that regulation was coming. That is not to say, however, that even if a bank in say January 2002 was certain that regulation would be implemented in October 2003, it would necessarily have changed its pricing or strategy in January 2002, since interchange fee levels for itself and its competitors were still at prior levels. Nor does it mean that a bank would necessarily wait until the actual date of the regulation to change its behavior. A bank would not offer a cardholder annual fees in, say, September 2003 based on pre-regulation interchange fee levels if it knew that the post-regulation levels would be in place two months later.

Our best estimate on timing is that there were at least some changes in bank behavior in early 2003 in anticipation of the regulatory intervention. ${ }^{34}$ The annual report for one of the major banks, ANZ, noted that in 2003 it had reshaped its "product set across the Australian Cards Issuing portfolio to address the impact of the Reserve Bank interchange reforms". ${ }^{35}$ There are a number of newspaper articles along the same lines in the period prior to October 2003. ${ }^{36}$ The Sunday Telegraph (Sydney), for example, reported in its September 21, 2003 edition that the five major banks had increased credit card fees by up to 50 percent in the previous 12 months. The article goes on to quote a bank executive who expressed that the rise in fees had the goal of making up for the loss in interchange income that would happen after the implementation of the regulatory scheme. ${ }^{37}$ In our analyses below, we consider whether we see any effect of regulation starting in 2003 and, alternatively, starting in 2004.

We analyse two questions: (1) How did the intervention affect prices to issuers, cardholders, merchants, and consumers? (2) What was the effect of the intervention on card use? Appendix A provides information on our data sources and detailed statistical results for interested readers.

\subsection{Effect on prices}

\subsubsection{Issuers and cardholders}

Visa Australia provided the data used in the calculations in this section. The dataset was constructed with information from the operating certificates that banks submit to the Visa organization. The dataset provides quarterly information on the number of Visa credit cards, credit card purchase volume, other service charges (that is, fees that issuers charge

\footnotetext{
${ }^{34}$ Some changes in fees may have been happened already in 2002.

${ }^{35}$ See ANZ (2003, p.31).

${ }^{36}$ See, for example, McKinnon (2001), Hanna (2002), Brammall (2002, 2003), Horan (2003), and Graeme (2003).

${ }^{37}$ See Horan (2003).
} 
cardholders, primarily annual fees and service fees), finance charges, and outstanding balances on credit cards in Australia between the third quarter of 1992 and the first quarter of $2005 .^{38}$

Between the last quarter of 1992 and the fourth quarter of 1999, real interchange income per Visa card grew at an average quarterly compound rate of about 4.2 percent, from around AU\$5.79 to around AU\$18.34, driven by the rise in purchase volume per card. ${ }^{39}$ Between the first quarter of 2000 and the third quarter of 2003, the quarter prior to the introduction of the new interchange rates, real interchange income per card grew at an average quarterly compound rate of about 3.12 percent, from around AU\$17.26 to around AU $\$ 26.55$.

Interchange-fee regulation was implemented in the fourth quarter of 2003. If we compare the first two quarters of 2003 with the first two of 2004, we find that issuers lost, on average and in real terms, about AU\$9.35 per card in interchange income per quarter, a loss of about 40 percent on total interchange income per card of about AU\$23.52 per quarter in the first two quarters of 2003.

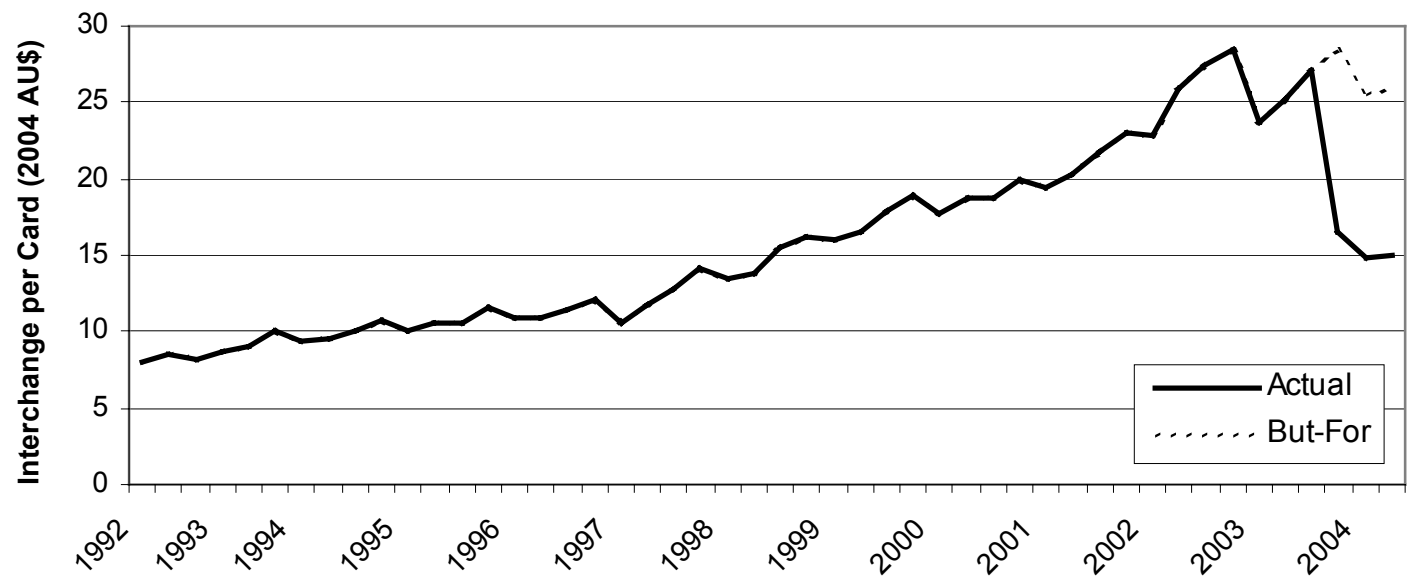

\section{Figure 1: Real interchange revenue per card}

A more interesting way to look at this loss is to ask how much the issuers would have made in interchange income in the absence of regulation. From this perspective, we calculate a "but for" interchange income per card under the assumption that the regulatory scheme was not implemented and the interchange rate remained at an average of 0.95 percent. We then subtract the actual interchange income per card from the "but for" interchange income per card and we find that, on average, in the first two quarters of 2004 issuers lost about AU $\$ 10.31$ per quarter per card. This represents a loss of about 42 percent with respect to the interchange income they would have obtained in the "but for" world. Figure 1 shows these facts.

The evidence thus suggests that issuers started losing, in real terms, roughly between AU\$9.30 and AU\$10.30 per card per quarter in interchange income as a consequence of

\footnotetext{
${ }^{38}$ At the time of this writing the information on other service charges and finance charges was available only through the second quarter of 2004.

${ }^{39}$ As noted above, all figures are reported in real 2004 Australian dollars.
} 
the RBA intervention. In the months that followed the introduction of the regulation (and likely in the months that preceded the regulation as well) they recovered between 30 and 40 percent of that loss through the imposition of higher fees.

Appendix A provides the support for this conclusion. A regression model that compares the level of real other service charges per card after regulation with the level before, controlling for seasonal effects, changes in the real purchase volume per card, and changes in unobserved factors over time, suggests that the regulation (or its anticipation) was accompanied by a rise in real other service charges of roughly 30 to 40 percent of the interchange loss amount. (As we discuss further in the appendix, the quarterly Visa data we used track closely with annual RBA data on fees. The increase in issuer annual and service fee revenue per card from 2001 to 2003 was AU\$20.84 from the RBA data and AU\$22.78 from the Visa data.) A similar model for real finance charges per card produces positive coefficients for the post-regulation period. The coefficients, however, are for the most part not statistically significant. Furthermore, we found no evidence of a structural break (associated with the RBA regulation) in the interest rate that issuers charge on outstanding balances.

The components of the "other service fees" variable from the Visa data are annual fees and service fees. Annual fees are fixed with respect to transaction volume. Service fees (such as late payment fees and over-limit fees) are also primarily fixed fees. A late payment fee, for example, is independent of the amount charged. ${ }^{40}$

In addition to the increases estimated above for these fixed fees, there has also been an impact on the level of rewards offered by issuers. The RBA has reported that the average reward decreased from 0.8 to 0.6 percent for most of the bank schemes. ${ }^{41}$ While rewards (miles or points accumulated as a function of purchase volume) affect marginal incentives to use cards, the way in which issuers have implemented changes has likely limited the impact on purchase volume. First, some of the changes have been in the form of caps on the number of reward points accumulated. For example, National Australia Bank (NAB) capped rewards on its Visa rewards card. It offers 1 point for each dollar spent up to AU $\$ 3,000$ per month. Above the $\$ 3,000$ a month spending threshold, cardholders receive 1 point for every two dollars spent, up to a maximum of 13,000 points a month. For cardholders below the AU\$3,000 threshold, the marginal incentive to use cards has not changed as a result of the imposition of the cap. ${ }^{42}$

For customers who are likely to exceed the monthly cap on a regular basis, the marginal incentives have changed on the NAB Visa rewards card. However, one of NAB's other responses to the regulation was to partner with American Express, in offering a

\footnotetext{
${ }^{40}$ The over-limit fee may be partially variable, in the sense that a consumer may be more likely to exceed the credit limit at higher purchase volumes. But it is not clear that higher over-limit fees would significantly affect consumer purchase volume on credit cards. Among other things, over-limit fees would appear to be more directly related to accumulated revolving balances as opposed to purchase volume (although the two are related).

${ }^{41}$ See Testimony of Dr. Philip Lowe, House of Representatives Standing Committee on Economics, Finance and Public Administration (EFPA) (2005), at pp.26-27. There is insufficient detail on this data point for us to conduct a detailed analysis. The RBA does not report, for example, how this estimate is constructed, nor does it provide a data series over time (or even which years are the beginning and end points). It is also unclear whether this includes rewards for cards issued on the American Express and Diners Club systems.

${ }^{42}$ The cost of having rewards cards has increased, which may result in fewer consumers deciding to hold them, but contingent on having a card, the marginal incentive to use a card has not changed for consumers below the threshold.
} 
rewards card without a cap (in fact offering 1.5 points for each dollar in the first year). Similarly, Westpac now offers an American Express rewards card and ANZ offers a Diners Club rewards card, both without rewards caps and both more generous than the MasterCard/Visa rewards cards from the respective banks. ${ }^{43}$ As we note below, while the interchange fee regulation appears to have had relatively little effect to date on overall card volume, it does appear to have switched cards from MasterCard and Visa to the American Express and Diners Club systems. ${ }^{44}$

What we have estimated is the short-run impact. Since cardholders are valuable assets - issuers spend considerable resources to acquire new cardholders and pay a premium on portfolio purchases - one would expect issuers to be cautious in raising prices quickly to their existing mature cardholder portfolio. Over the longer run, as cardholders switch from one issuer to another, one would expect price effects to be more fully realized.

\subsubsection{Acquirers, merchants, and consumers}

According to the RBA, the reduction in interchange fees imposed by regulation led to a reduction in merchant service fees (that is, the merchant discount). The average merchant service fee that the now regulated systems charge fell from 1.41 percent immediately before regulation to 0.99 percent in the quarter ending June $2004 .{ }^{45}$ The RBA estimates that the fall in the merchant discount represents savings to merchants of over $\$ 500$ million per annum. ${ }^{46}$

We consider the extent to which this decrease in costs to merchants was passed on to consumers. ${ }^{47}$ To begin with, the reduction in cost was quite small for retailers. The cost of a credit-card transaction made with a BankCard, MasterCard or Visa card fell by 0.42 percent. However, these transactions comprise only about a quarter of retail transactions.

According to the RBA, total purchase volume on credit and charge cards in 2004 was roughly AU $\$ 147$ billion, and the regulated systems accounted for 83.8 percent of that (that is, roughly 123 billion). Total household consumption in 2004 was roughly AU\$500 billion, so that purchase volume on regulated credit cards represented roughly 25 percent of total consumption. To be conservative, we take the card share of retail transactions to be 50 percent, which will likely overstate the card share for many merchants, especially those

\footnotetext{
${ }^{43}$ See, Westpac Bank, at http://www.westpac.com.au/internet/publish.nsf/Content/PBCCCSCR+Altitude; ANZ Bank, at http://www.anz.com/australia/support/library/MediaRelease/MR20030912.pdf

${ }^{44}$ See EFPA (2005, p.25). See also, Diners Club of Australia website, at http://www.dinersclub.com.au/s06_media/p62_view.asp?id=144

${ }^{45}$ See RBA (2004, p.9).

${ }^{46}$ We have not made any attempts to verify this independently. In any case, according to the RBA, total nominal purchase volume on credit and charge cards was about $\$ 147$ billion in 2004. According to the RBA, Bankcard, Visa and MC accounted for about 83.8 percent of total volume in that year, that is they accounted for about $\$ 123$ billion. The reduction in the merchant discount was 0.0042 percentage points, which gives savings to merchants of roughly $\$ 517$ million.

${ }^{47}$ The RBA claimed in testimony before the Australian House of Representatives in 2005 that these cost savings would be passed on almost entirely to final consumers. It reasoned that the retail sector overall was not concentrated even though particular segments such as supermarkets were. This analysis ignores the point, of course, that the extent of pass through depends on the structure of the relevant market, which is not overall retail but the individual markets that comprise it. Testimony of Mr. Ian MacFarlane, House of Representatives Standing Committee on Economics, Finance and Public Administration (EFPA) (2005), at pp.23-24.
} 
in the service sector. ${ }^{48}$ Taking this 50 percent estimate, then the average reduction in overall merchant costs as a result of the interchange fee reduction was 50 percent of 0.42 percent or 0.21 percent.

There are three reasons, mentioned earlier, why we would expect that prices to consumers would have fallen by less than 0.21 percent. First, this decrease in costs amounts to roughly 8 cents on an AU $\$ 40$ transaction. The empirical literature on price rigidities makes it doubtful that a decrease in cost of this small magnitude would be passed on to consumers quickly. Second, many of the significant retail markets in Australia are highly concentrated. Given the small decrease in cost it is reasonable to approximate the demand curve facing these merchants with a linear demand curve. In this case, pass through rates will be less than 100 percent. Third, it seems that the empirical evidence on pass through - while not specific to Australia - finds rates of less than 100 percent more often than rates of more than 100 percent. ${ }^{49}$ With a 50 percent pass through rate, the reduction in prices to consumers from the RBA's interchange fee reduction would be 0.105 percent. That amounts to roughly 4 cents on a AU $\$ 40$ transaction. It would not require much in the way of price rigidities for merchants to decide not to adjust prices in the short run.

The very little empirical evidence there is suggests that, in fact, merchants have tended not to pass through the reduction in the merchant discount to consumers in the form of lower prices. Cannex, an independent research group, surveyed merchants in Australia regarding the impact of the interchange fee regulation on their regular business practices. ${ }^{50}$ Among merchants who reported a change in the merchant discount during the previous year, less than 5 percent declared that they had reduced prices to consumers. On the other hand, more than 20 percent reported that their profits had increased and almost 60 percent reported that they had not experienced any changes in their regular operations.

Surcharging for credit card transactions, following the repeal of non-surcharge rules, is still the exception in Australia, as it has been in other countries. ${ }^{51}$ One survey of Australian merchants in November 2004 found that only 2.3 percent of all merchants surcharged, with larger merchants slightly more likely to surcharge, at slightly over 5 percent. ${ }^{52}$ A different survey found that 7 percent of all merchants surcharged regularly. ${ }^{53}$ It is also worth noting that the average surcharge was 1.8 percent, which is higher than the merchant discount fee on credit card transactions, and also almost surely higher than any differential between the

\footnotetext{
${ }^{48}$ The 25 percent figure of share of cards of total consumption may be an underestimate of the percent of retail transaction dollars on cards since the consumption figure includes some non-retail merchants where cards are not commonly used. Unfortunately, more precise data are not available for Australia. In the United States, where the card share of total consumption is only slightly higher than Australia, the portion of transactions at merchants paid for with cards is slightly under 50 percent for retail and travel and entertainment merchants, and less than 10 percent for service merchants.

${ }^{49}$ See supra notes $25-26$.

${ }^{50}$ See Cannex Australia (2004).

${ }^{51}$ Only about 10 percent of merchants imposed surcharges in the Netherlands, and only about 5 percent of merchants imposed surcharges in Sweden. Surcharging is also uncommon in the United Kingdom. See Evans \& Schmalensee (2005b, p.27).

${ }^{52}$ See Network Economics Consulting Group (NECG) (2005, p.46), citing East \& Partners 2004, “Australian merchant acquiring and cards markets: Multiclient market analysis report," December.

${ }^{53}$ The survey reported that 19 percent of merchants "sometimes" surcharged, but it is unclear how commonly and on what criteria they did so. Two other surveys that asked incidental questions on surcharging reported that 12 percent and 2.9 percent, respectively, of respondents surcharged (although the frequency of surcharging was unknown). See NECG (2005, p.44).
} 
costs to merchants of processing credit cards versus other forms of payment. This suggests that at least some of the surcharging that takes place may be opportunistic and does not increase the efficiency of relative prices for payment instruments facing consumers.

\subsection{Effect on transaction volume}

If the preceding estimates are correct we can make some surmises about the effect of the regulatory intervention on transaction volumes. It appears that cardholders are not facing substantially different prices at the point of sale for using credit cards. The usage prices assessed by the issuers do not appear to have risen generally and remain negative in many cases. At the same time the preponderance of merchants are not availing themselves of surcharging. Therefore, holding the number of cards constant we have no reason to expect more than a modest change in the volume of transactions in the short run.

However, the increase in fixed fees means that we would expect that fewer individuals have cards. The elasticity of demand of card membership with respect to membership and usage fees determines the relative decline in cardholders. We would expect that any decline in usage of MasterCard and Visa cards as a result of a decline in membership would take place gradually as people adjust the number of cards they have. A further complication is that the RBA did not impose any price regulation on American Express and Diners Club. Some banks have started issuing American Express cards, in particular, in response to the higher effective price they receive for those cards relative to the regulated MasterCard and Visa cards. Therefore, from the standpoint of a regulatory desire to reduce the use of cards, we need to consider total credit-card transactions and not just those of the regulated systems.

Despite a rather massive regulatory intervention that eliminated about 30 percent of issuer revenue in the stroke of a pen, ${ }^{54}$ there is little evidence to date that the intervention has significantly affected the use of credit cards in Australia. At the same time it appears that some proportion of transaction volume has moved from association cards to proprietary cards. ${ }^{55}$

Figure 2 shows the level and growth rate of real purchase volume on credit cards along with key points in the timeline for the regulatory intervention. Despite the massive degree of the RBA's intervention, there appears to be no evidence of any effect of the intervention on the use of cards. Table 4 goes into more detail by showing the trends over time in several measures of card use.

Other than the number of accounts, the indicators of credit-card use grew at an increasing rate through 1999 and then grew at a declining rate through 2002. Assessing the impact of the RBA's regulation depends on our assumptions about card industry performance in the absence of regulation. For example, if the question is whether the regulations stopped the growth of card ownership and usage, then the answer is "no" - all card metrics continued to grow post-regulation. Our main focus is on two different questions, namely (1) whether growth rates were lower post-regulation than pre-regulation and (2) whether the decline in the growth rates that was taking place pre-regulation accelerated or decelerated.

\footnotetext{
${ }^{54}$ In this calculation we are excluding revenues derived from the so-called "interest margin".

${ }^{55}$ According to the RBA data, the regulated systems accounted for 86.3 percent of the total value of credit card purchases in September 2003. In June 2005 they accounted for 83 percent. See the market-share data available at http://www.rba.gov.au/Statistics/Bulletin/C02hist.xls
} 


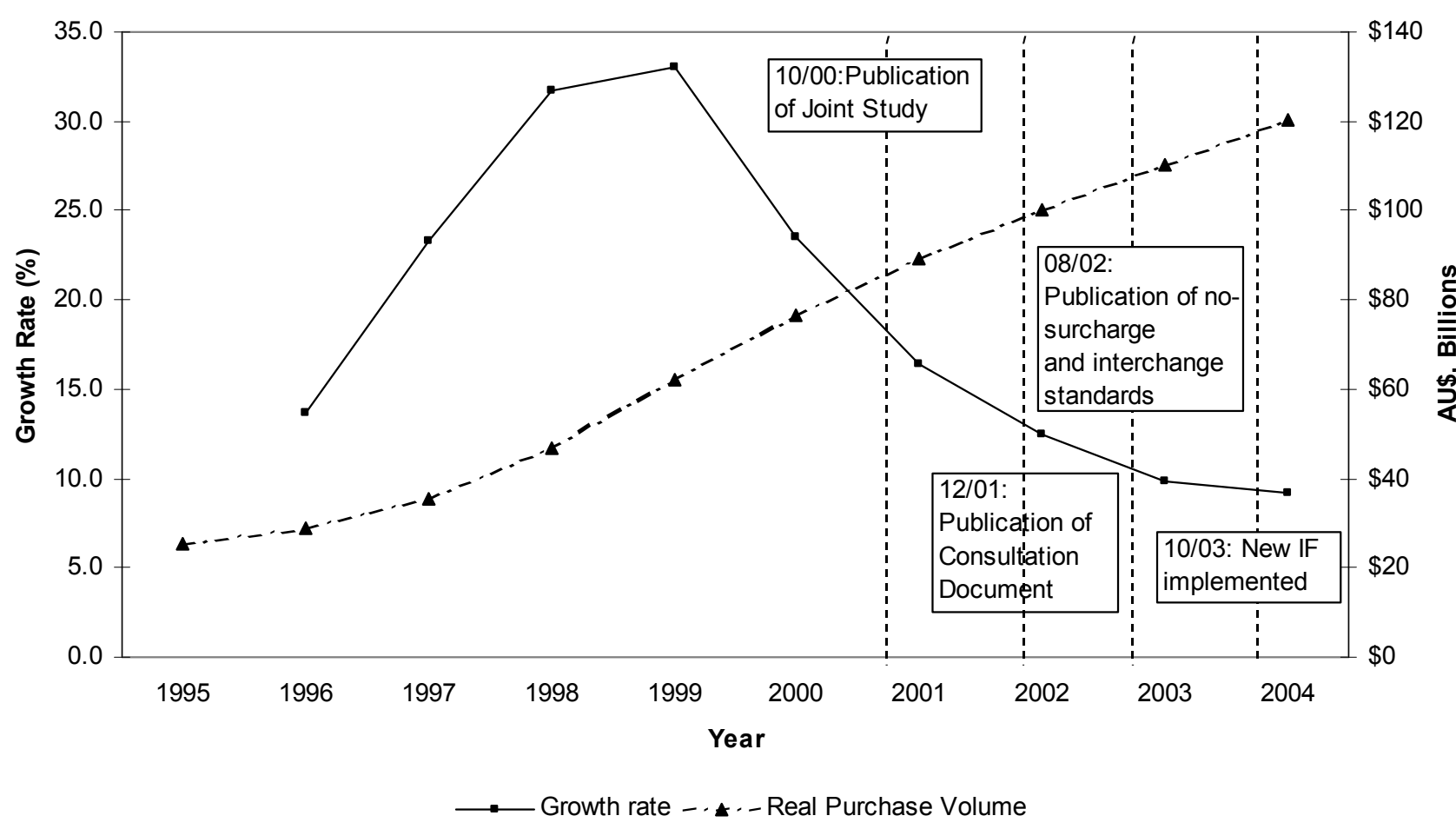

Figure 2: Real purchase volume on credit cards: 1995 - 2004

Source: RBA (2005b).

The aggregate data suggest that (1) industry growth was lower after regulation than before, with the exception of the number of accounts, and (2) the decline in the rates of growth that started around 1999 has continued, again with the exception of the number of accounts, but has not accelerated. These basic empirical regularities are confirmed by our detailed analysis discussed below. The first comparison would say that regulation has lowered the growth rates, while the second would say that the decline in the growth rates was already taking place and the regulation had relatively little impact. Our prior is that the second comparison is more appropriate, as we observe a significant slowdown in the rate of growth in the pre-regulation period. We acknowledge, however, that our analysis does not come close to explaining the dramatic shifts in industry output that have taken place either the accelerating growth leading up to 1999 or the decelerating growth following 1999. Therefore, we believe it is at least possible that absent regulation, growth rates of the different card metrics might have levelled off, or even increased. ${ }^{56}$

\footnotetext{
${ }^{56}$ For example, the entry of Virgin as an issuer in 2004 could have increased output, all else equal. To the extent that is true, our comparisons would underestimate the impact of the RBA's regulation. We do not have detailed and systematic data on industry concentration, or on entry and exit, to attempt to control for these factors.
} 


\begin{tabular}{|c|c|cc|c|c|}
\hline Accounts & $\begin{array}{c}\text { Purchase } \\
\text { Transaction } \\
\text { s }\end{array}$ & $\begin{array}{c}\text { Purchase } \\
\text { Transaction } \\
\text { s per } \\
\text { Account }\end{array}$ & $\begin{array}{c}\text { Real } \\
\text { Purchase } \\
\text { Volume }\end{array}$ & $\begin{array}{c}\text { Real } \\
\text { Purchase } \\
\text { Volume per } \\
\text { Account }\end{array}$ \\
\hline 1996 & 7.7 & 14.2 & 6.1 & 13.7 & 5.6 \\
1997 & 5.6 & 19.7 & 13.3 & 23.3 & 16.7 \\
1998 & 6.1 & 30.8 & 23.2 & 31.7 & 24.2 \\
1999 & 5.9 & 32.5 & 25.1 & 33.0 & 25.6 \\
2000 & 7.0 & 24.0 & 15.9 & 23.5 & 15.5 \\
2001 & 2.5 & 16.9 & 14.0 & 16.4 & 13.5 \\
2002 & 1.5 & 13.9 & 12.2 & 12.4 & 10.7 \\
2003 & 4.7 & 8.9 & 4.0 & 9.9 & 4.9 \\
2004 & 6.0 & 8.7 & 2.5 & 9.2 & 3.0 \\
\hline
\end{tabular}

Table 4: Annual growth rates of indicators of credit card use, all credit cards, 19962004

Source: all the growth rates have been calculated on the basis of RBA (2005c).

In order to address the first question - that is, whether growth rates were lower postregulation - we estimated a number of simple regression models of the quarterly growth rates of the credit card use variables on a set of quarterly binary variables, a binary variable that takes on the value 1 between 2000 and 2002 and 0 otherwise, ${ }^{57}$ and a binary variable that takes on the value 1 starting in 2003 . The results are reported in Table $4 \mathrm{a}^{58}$

The interpretation of these results is straightforward. In the case of the number of accounts, growth rates in the regulated period have been no different from what they were through 2000 and higher than they were in 2001-2002. In the case of all other variables, however, growth rates in the regulated period have been lower than they were through 1999 and also lower than they were in 2000-2002. From this perspective, the regulated period has been associated mostly with lower growth rates in the indicators of credit card use.

\footnotetext{
${ }^{57}$ In the accounts model this binary variable takes on the value 1 in 2001-2002 rather than in 2000-2002. ${ }^{58}$ All the regressions include binary variables for the second, third, and fourth quarters on the right hand side. When the growth rate in the number of accounts is the dependent variable, we control for changes in population and income per capita. In the case of the number of purchases and real purchase volume, we control for changes in real consumption. In the case of the number of purchases per account and real purchase volume per account, we control for changes in consumption per capita.
} 


\begin{tabular}{|c|c|c|}
\hline & Coefficient & P-value \\
\hline \multicolumn{3}{|c|}{ Growth in Number of Accounts } \\
\hline $2001-2002$ & -0.0096 & 0.000 \\
\hline 2003-2005 & -0.0013 & 0.682 \\
\hline \multicolumn{3}{|c|}{ P-value for $F$ test of equality between binary-variable coefficients $=0.0116$} \\
\hline \multicolumn{3}{|c|}{ Growth in Number of Purchases } \\
\hline $2000-2002$ & -0.013 & 0.214 \\
\hline $2003-2005$ & -0.033 & 0.001 \\
\hline \multicolumn{3}{|c|}{ P-value for F test of equality of binary-variable coefficients $=0.0184$} \\
\hline \multicolumn{3}{|c|}{ Growth in Number of Purchases per Account } \\
\hline $2000-2002$ & -0.007 & 0.362 \\
\hline 2003-2005 & -0.032 & 0.002 \\
\hline \multicolumn{3}{|c|}{$\mathrm{P}$-value for $\mathrm{F}$ test of equality of binary-variable coefficients $=0.0026$} \\
\hline \multicolumn{3}{|c|}{ Growth in Real Purchase Volume } \\
\hline $2000-2002$ & -0.012 & 0.278 \\
\hline $2003-2005$ & -0.033 & 0.001 \\
\hline \multicolumn{3}{|c|}{$\mathrm{P}$-value for $\mathrm{F}$ test of equality of binary-variable coefficients $=0.0259$} \\
\hline \multicolumn{3}{|c|}{ Growth in Real Purchase Volume per Account } \\
\hline $2000-2002$ & -0.007 & 0.445 \\
\hline 2003-2005 & -0.032 & 0.002 \\
\hline $\mathrm{P}-\mathrm{V}$ & of binary-v & \\
\hline
\end{tabular}

Table 4a: Regression of the quarterly growth rates of the credit-card-use variables on a binary variable for 2000-2002 and a binary variable for the regulated period ( $P$ values calculated on the basis of Newey-West standard errors)

We then addressed the second question - that is, has the decline in the growth rates that started in the late 1990s accelerated or decelerated with regulation? We used regression methods to examine more carefully whether credit card activity grew more slowly than it would have in a world without the RBA regulation. We studied the growth patterns in greater detail by regressing the growth rates of the relevant variables on a linear spline function. ${ }^{59}$ We performed the analysis with annual data and quarterly data. With quarterly data, we calculated proportional growth rates between quarter $q$ and quarter $(q-1){ }^{60}$

We describe the model on the basis of quarterly data. We first created a linear trend $t$ that starts at 1 in the first quarter for which growth rates can be calculated and grows by 1 every quarter through the first quarter of 2005 . We then defined the spline time dimension variables as follows:

\footnotetext{
${ }^{59}$ On linear spline functions see, for example, Poirier (1976, ch. 2); Poirier and Garber (1974); Johnston (1983, p.392ff); and Greene (1993, p.235ff). For a study that uses linear splines in the context of testing for the existence of unit roots in economic time series, see Perron (1989). For a discussion of the various Perron models, see, for example, Enders (2004, pp. 200-207).

${ }^{60} \mathrm{We}$ also performed the analysis with the growth rates calculated between quarters $q$ and $(q-4)$. Although the magnitude of the coefficients was, of course, different, the substance of the conclusions we draw did not change much.
} 


$$
\begin{aligned}
& \mathrm{X}(\mathrm{t})=t, t=1,2, \ldots, T ; \\
& \mathrm{Y}(\mathrm{t})=\max (0, t-a) ; \\
& \mathrm{Y}(\mathrm{t})^{\prime}=\max (0, t-b) ; \text { and } \\
& \mathrm{Z}(\mathrm{t})=\max (0, t-c) .
\end{aligned}
$$

In this model, $a$ is the number that corresponds to the last quarter of 1999 in the trend sequence, $b$ is the number that corresponds to the last quarter of 2000 , and $c$ is the number that corresponds to the last quarter of 2002.

Think of a world where the number of credit card accounts, the number of credit card purchases, and the real purchase volume on credit cards are functions of a set of demand shifters. For example, the number of credit card accounts is a function of population and income per capita, and the number of credit card purchases is a function of real consumption. Then in order to assess whether there have been significant changes in the trend of the growth rates of the credit card use variables, we can estimate models of the following form:

$$
\begin{aligned}
& \mathrm{G}_{\mathrm{CC}}(\mathrm{t})=\alpha_{1}+\delta_{11} \mathrm{X}(\mathrm{t})+\delta_{12} \mathrm{Y}(\mathrm{t})+\delta_{13} \mathrm{Z}(\mathrm{t})+\gamma_{1} \mathrm{C}(\mathrm{t})+\mathrm{u}_{1}(\mathrm{t}) \text {, or } \\
& \mathrm{G}_{\mathrm{CC}}(\mathrm{t})=\alpha_{2}+\delta_{21} \mathrm{X}(\mathrm{t})+\delta_{22} \mathrm{Y}(\mathrm{t})^{\prime}+\delta_{23} \mathrm{Z}(\mathrm{t})+\gamma_{2} \mathrm{C}(\mathrm{t})+\mathrm{u}_{2}(\mathrm{t}) .
\end{aligned}
$$

In these models, $\mathrm{G}_{\mathrm{CC}}(\mathrm{t})$ stands for the growth rate of the credit-card-use variable in question and $\mathrm{C}(\mathrm{t})$ stands for the growth rate of the relevant demand shifter. These models focus on the percentage-point change in growth rates over time. ${ }^{61}$

The $\delta_{i 1}$ parameters (for $\mathrm{i}=1,2$ ) capture the trend in the growth rate between the starting point and 1999 (or between the starting point and 2000). The $\delta_{\mathrm{i} 2}$ parameters capture the change in the trend of the growth rate over 1999-2002 relative to the previous period (or 2000-2002 relative to the previous period). The $\delta_{\mathrm{i} 3}$ parameters, finally, capture the change in the trend of the growth rate over 2003-2004 (the regulatory period) relative to 1999- 2002 (or 2000-2002).

The estimated parameters with the p-values calculated on the basis of the Newey-West standard errors are reported below in Table $5 .^{62}$

\footnotetext{
${ }^{61}$ The results we obtain do not change in any substantive manner if we exclude the demand shifters from the estimated regressions.

${ }^{62}$ All the regressions include binary variables for the second, third, and fourth quarters on the right hand side. When the growth rate in the number of accounts is the dependent variable, we control for changes in population and income per capita. In the case of the number of purchases and real purchase volume, we control for changes in real consumption. In the case of the number of purchases per account and real purchase volume per account, we control for changes in consumption per capita. We also tried estimating the models via instrumental variables - we instrumented the growth in real consumption and the growth in real consumption per capita. We calculated the Newey-West standard errors for the IV-estimated coefficients. Overall, as far as the trend coefficients are concerned, the results were not substantially different from the ones obtained via OLS with Newey-West standard errors. We also calculated feasible-generalized-leastsquares (Prais-Winsten) estimates. The conclusions we draw did not change under the FGLS approach.
} 


\begin{tabular}{|c|c|c|}
\hline & Coefficient & P-value \\
\hline \multicolumn{3}{|c|}{ Growth in Number of Accounts } \\
\hline $\mathrm{d}(1)$ & 0.0001 & 0.592 \\
\hline$d(2)$ & -0.0018 & 0.001 \\
\hline $\mathrm{d}(3)$ & 0.0039 & 0.000 \\
\hline \multicolumn{3}{|c|}{ Growth in Number of Purchases } \\
\hline $\mathrm{d}(1)$ & 0.0021 & 0.000 \\
\hline$d(2)$ & -0.0066 & 0.000 \\
\hline$d(3)$ & 0.0044 & 0.003 \\
\hline \multicolumn{3}{|c|}{ Growth in Number of Purchases per Account } \\
\hline$d(1)$ & 0.0018 & 0.001 \\
\hline$d(2)$ & -0.0049 & 0.000 \\
\hline$d(3)$ & 0.0010 & 0.499 \\
\hline \multicolumn{3}{|c|}{ Growth in Real Purchase Volume } \\
\hline $\mathrm{d}(1)$ & 0.0020 & 0.002 \\
\hline$d(2)$ & -0.0063 & 0.000 \\
\hline$d(3)$ & 0.0044 & 0.005 \\
\hline \multicolumn{3}{|c|}{ Growth in Real Purchase Volume per Account } \\
\hline $\mathrm{d}(1)$ & 0.0016 & 0.014 \\
\hline$d(2)$ & -0.0047 & 0.001 \\
\hline$d(3)$ & 0.0010 & 0.509 \\
\hline
\end{tabular}

Table 5: Regression of the growth rate of the credit-card-use variables on a linear spline function on the basis of quarterly data, 1994-2005 (P-values calculated on the basis of Newey-West standard errors)

The results, based on quarterly growth rates, show the following. All of the models estimated show a positive point estimate for the trend that starts in 2003. In three of the models, the relevant coefficients are statistically significant - the exceptions are purchases per account and real purchase volume per account. These models convey the idea either that the trend of growth of the relevant card-use variable accelerated during the regulated period (for example, number of accounts) or that the decline in the trend of growth that had started in the late 1990s decelerated during the regulated period (for example, number of purchases).

The two models that raise some questions are the ones estimated in the growth rate for the number of purchases per account and real purchase volume per account. They both show a positive coefficient for the trend that starts in 2003 but the coefficients are not statistically significant. (A simple examination of Table 4, furthermore, shows that these two series seem to have exhibited considerably lower rates of growth in the post-regulation period than in the pre-regulation period as compared to other indicators of credit card use.) Whether the regulation had any impact in terms of curtailing purchases per account and purchase volume per account is thus an open issue.

Overall, taking into account existing trends in the growth rates of card variables, there is little evidence that the regulatory intervention has affected overall card use in the admittedly short period of time examined here. Figure 3 below, however, reveals that there 
have been important compositional changes - volume has shifted from the regulated systems to the unregulated ones. ${ }^{63}$ More specifically, between October 2003 and June 2005 the share of American Express and Diners Club increased by roughly 21 percent in terms of the number of purchases and by roughly 19 percent in terms of the value of purchases. This has happened because, as a consequence of regulation, relative prices seem to have changed. First, the relative price that issuers receive from a Visa or MasterCard transaction has declined relative to, say, an American Express transaction, since interchange has been capped for Visa and Master Card but American Express is allowed to sign issuing deals with banks under no interchange ceiling. Therefore, issuers have an incentive to shift volume to American Express, and they have. Secondly, the price of a card (or account) that cardholders face may have increased for the Visa and MasterCard cards relative to the proprietary ones, since Visa and MC issuers have attempted to recover some of the lost interchange income via an increase in other service charges, most of which are fixed fees. (Of course, in light of the fact that Visa and MasterCard issuers have raised other service charges, American Express and Diners Club may have done the same, so it is not altogether clear whether this relative price has changed much or not.)

Note, by the way, that the shift in volume from the regulated systems to the unregulated ones has a "perverse" effect on prices. In other words, the merchant discount on the regulated systems has come down significantly and the merchant discount on the unregulated systems has declined slightly, but it is considerably higher than the associations' pre-regulation merchant discount. Although the pure price effect leads to a lower average merchant discount, the compositional-change effect leads to a higher average merchant discount. (Of course, it will take an extremely large compositional change effect to produce an average merchant discount rate that is higher than the average pre-regulation rate.)

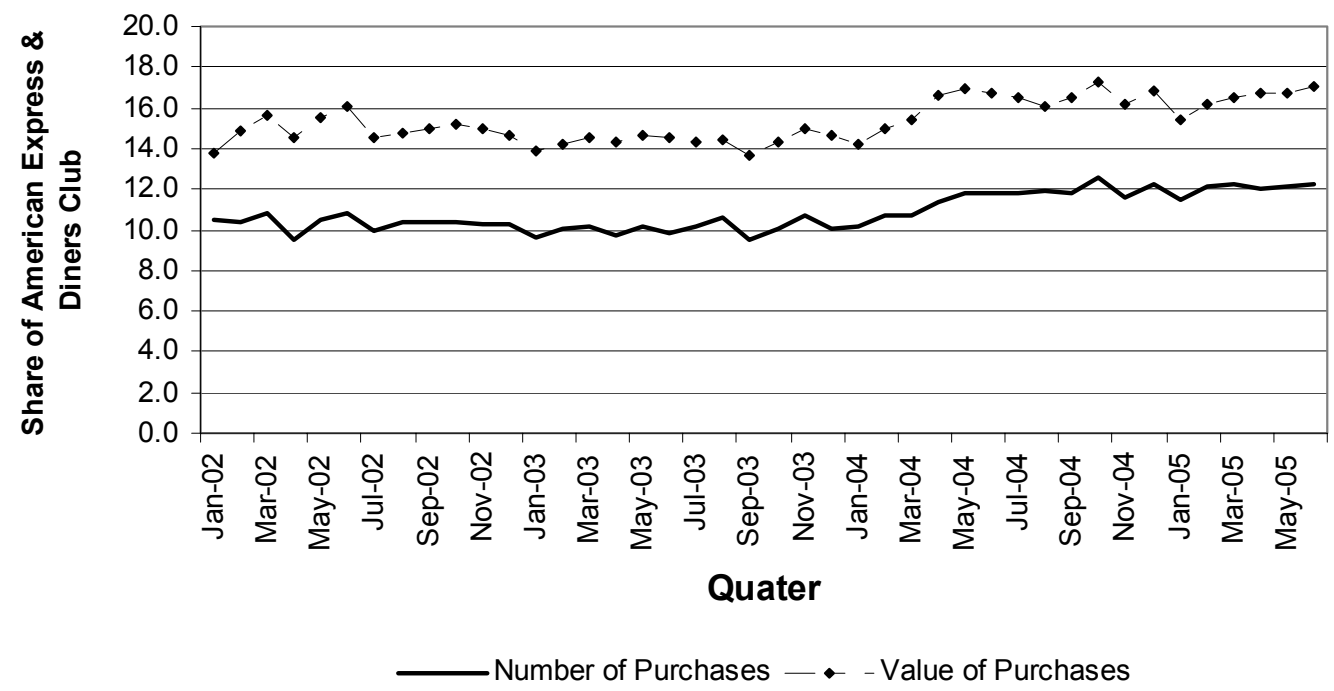

Figure 3: Share of American Express and Diners Club (in terms of number of purchases and value of purchases)

Source: RBA (2005d)

\footnotetext{
${ }^{63}$ Analysis of Visa data on card and volume also indicates that Visa output declined relative to total industry output following regulation.
} 


\section{Analysis of the RBA intervention}

The RBA's regulation of interchange fees has had some economic consequences that were entirely predictable and hardly surprising and others that raise some interesting questions both for regulators and students of two-sided markets.

One predictable result is that a massive reduction in revenue from one side of a twosided market had consequences on the other side. Banks lost roughly $\$ 490$ million in interchange fee revenue but appear to have regained between 30 and 40 percent of that through increased membership fees for cardholders. We believe this is a lower bound on the portion passed on to cardholders because of the cycle of replacing cards.

Another predictable result is the absence of evidence that consumer prices have fallen as a result of lower merchant discounts. This is not surprising because the cost savings are too small to be measurable with any degree of confidence. However, based on the economics literature on pass-through effects, we believe that it is highly unlikely that consumers have received any significant benefit over the period of time considered given the likely sticky prices and high concentration in the Australian retail sector.

Two results are, viewed prospectively, surprising. It appears that issuers have chosen thus far to adjust their pricing structures mainly through fixed fees - that is, fees that are independent of transaction volume. That is so despite a reduction in the variable revenue they received from the merchant side that had translated into negative variable prices on the cardholder side. Related to this is the finding that the near halving of interchange fees has not thus far led to a substantial reduction in card use. ${ }^{64}$ That is to be expected for now given that marginal prices for completing transactions with cards have not changed significantly as a result of the regulation.

Over time we would expect a reduction in total credit-card use on the regulated side as a result of the decrease in the number of cardholders. However, it is difficult to predict the magnitude of that reduction without knowing the responsiveness of cardholders to increased membership fees. As noted, offsetting this decrease will be the increased use of cards from the unregulated proprietary systems. It appears that especially for high-spenders on rewards cards, issuers have made a serious, and predictable, effort to move them from the regulated associations to the unregulated proprietary systems. The RBA's hope that regulating the associations' interchange fees would exert substantial downward pressure on the American Express and the Diners Club merchant discount rates is particularly unlikely to be realized as high-spend rewards cardholders move to the unregulated systems.

\section{$7 \quad$ Conclusions}

Did the RBA regulatory intervention achieve its goals? One answer is that it is too soon to tell. It takes time for markets to adjust and it may be that banks and merchants will make further adjustment over time. But to the extent that the first couple of years provide information, the evidence indicates that the intervention has not achieved its goals for a

\footnotetext{
${ }^{64}$ As we note above, growth rates of card output are lower post-regulation than pre-regulation. Although our prior is that this is a continuation of pre-existing declines in the growth rate, we do not rule out the possibility that growth rates might have levelled off absent regulation, and that the regulation has therefore lowered card growth.
} 
reason that was not apparent to either the RBA or the card associations at the time the intervention was being debated.

The purpose of the intervention was to raise the cost of transacting with credit cards, to bring social costs and benefits in alignment, and thereby to reduce the use of what was thought to be an inefficient instrument. The RBA saw the interchange fee as the source of the problem because banks subsidized card use to get this revenue source and merchants could not make cardholders bear the differential costs of card use. If the intervention had resulted in banks raising usage fees in lockstep with the reduction in interchange fees or if merchants had raised surcharges to account for the interchange fees, the RBA would have achieved its objectives.

Neither expectation was fulfilled. For the most part, it seems that banks raised fixed fees and left the per-transaction incentives alone. In addition, the banks started to switch volume from the regulated to the unregulated systems. By and large, merchants have not chosen to impose surcharges. Thus far the incentives that cardholders face to use cards at the point of sale do not seem to have changed radically. If these patterns persist, the effects of the RBA regulation, if any, will likely take place through a reduction in total cards on the regulated systems.

This result does not just provide further support for the law of unintended consequences. It also raises interesting research questions. For the study of two-sided markets, it emphasizes that further work is needed to understand the role of two-part tariffs in guiding membership and usage decisions. This is an important topic for many two-sided industries since these two-part tariffs are quite common. For the study of regulatory interventions, it emphasizes that we need to know more about how two-sided businesses set prices to design interventions in those industries that can accomplish specified goals.

\section{$8 \quad$ References}

ANZ (2003) Annual Report.

Armstrong, Marcia (1991) "Retail Response to Trade Promotion: An Incremental Analysis of Forward Buying and Retail Promotion," unpublished doctoral dissertation, School of Management, University of Texas at Dallas.

Australian Bureau of Statistics (2001) 2001 Census Basic Community Profile and Snapshot.

http://www.abs.gov.au/ausstats/abs@census.nsf/4079a1bbd2a04b80ca256b9d00208f92/7d d97c937216e32fca256bbe008371f0!OpenDocument

Australian Bureau of Statistics (2003) Year Book Australia. http://www.abs.gov.au/Ausstats/abs@.nsf/Lookup/361F400BCE3AB8ACCA256CAE0005 $\underline{\text { 3FA4 }}$

Australian Bureau of Statistics (2005) Household Final Consumption Expenditure. March. 
Australian Prudential Regulation Authority (2005) Monthly Banking Statistics. July. http://www.apra.gov.au/Statistics/loader.cfm?url=/commonspot/security/getfile.cfm\&Page $\underline{\mathrm{ID}=9124}$

Baxter, William (1983) "Bank Interchange of Transactional Paper: Legal Perspectives," Journal of Law and Economics, 26: 541-588.

Besley, Timothy and Harvey Rosen (1999) "Sales Taxes and Prices: An Empirical Analysis," National Tax Journal, 52: 157-178.

Borenstein, Severin, C. Cameron, and R. Gilbert (1997) "Do Gasoline Prices Respond Asymmetrically to Crude Oil Price Changes?" Quarterly Journal of Economics 112: 305339 (February).

Brammall, Bruce (2002). "Watchdog Fears ANZ Card Hikes,” Herald Sun, November 5.

Brammall, Bruce (2003) “Bank May Ditch Reward Scheme,” Herald Sun, February 20.

Bulow, Jeremy and Paul Pfleiderer (1983) "A Note on the Effect of Cost Changes on Prices," Journal of Political Economy, 91: 182-185.

Bureau of Transportation Statistics (2000) "Airport Activity Statistics of Certificated Air Carriers: $\quad$ Summary Tables 2000," http://www.bts.gov/publications/airport activity_statistics_of_certificated_air_carriers/200 $\underline{0 / \text { tables/table01.html }}$

Cannex Australia (2004) Card reforms in Australia: Monitoring of market effects, October.

Carlton, Dennis W. (1986) "The Rigidity of Prices," American Economic Review, 76: 63758.

Chakravorti, Sujit (2003) "Theory of Credit Card Networks: A Survey of the Literature," Review of Network Economics, 2: 50-68.

Chevalier, Michel and R. Curhan (1976) "Retail Promotions as a Function of Trade Promotions: A Descriptive Analysis," Sloan Management Review, 18: 19-32.

Cotterill, Ronald (1998) "Estimation of Cost Pass Through to Michigan Consumers in the ADM Price Fixing Case," Food Marketing Policy Center, University of Connecticut, Research Report No. 39.

Cotterill, Ronald (2000) "Dynamic Explanations of Industry Structure and Performance," presented at the USDA Conference "The American Consumer and the Changing Structure of the Food System," May 3-5, 2000.

Enders, Walter (2004) Applied Econometric Time Series. John Wiley and Sons: New York. Euromonitor International (2005a) Department Stores in Australia. October. 
Euromonitor International (2005b) Grocery Stores, Food Retailers and Supermarkets in Australia. October.

Euromonitor International (2005c) Superstores and Warehouse Clubs in Australia. October.

Evans, David S., and Richard Schmalensee (2005a) Paying with Plastic: The Digital Revolution in Buying and Borrowing. Second Edition. MIT Press: Cambridge, MA.

Evans, David S., and Richard Schmalensee (2005b) "The Economics of Interchange Fees and Their Regulation: An Overview," paper presented at a Conference Interchange Fees in Credit and Debit Card Industries: What Role for Public Authorities? Federal Reserve Bank of Kansas City, Santa Fe, New Mexico, May 4-6.

Evans, David S., and Richard Schmalensee (2005c) "The Industrial Organization of Markets with Two-Sided Platforms," NBER Working Paper Series, No. 11603, September.

Goldberg, Pinelopi and Michael Knetter (1997) "Goods Prices and Exchange Rates: What Have We Learned?” Journal of Economic Literature, 35: 1243-1272.

Goldberger, Arthur S. (1991) A Course in Econometrics. Harvard University Press: Cambridge, Massachusetts.

Graeme, James (2003) “Loyalty is No Longer Paying Off,” Sunday Telegraph, May 4.

Greene, William H (1993) Econometric Analysis. Macmillan: New York.

Hamilton, James (1994) Time Series Analysis. Princeton University Press: Princeton, NJ.

Hanna, Jim (2002) "Fed: Consumers to Save \$500m-Plus Under Credit Card Shake-Up," AAP Newsfeed, August 27.

Hansen, Bruce (2001) "The New Econometrics of Structural Change: Dating Breaks in U.S. Labor Productivity,” Journal of Economic Perspectives, 15: 1065-1076.

Horan, Matthew (2003) "Banks Up Card Fees Yet Again," Sunday Telegraph, September 21.

House of Representatives Standing Committee on Economic Economics, Finance and Public Administration (2005) Official Committee Hansard. August 12.

http://www.aph.gov.au/hansard/reps/commttee/R8516.pdf

HSN Consultants (2003) The Nilson Report. No. 783, March.

Huber, Peter J. (1964) "Robust Estimation of a Location Parameter," Annals of Mathematical Statistics, 35: 73-101.

Jackson, William, III (1997) "Market Structure and the Speed of Price Adjustments: Evidence of Non-monotonicity," Review of Industrial Organization, 12: 37:57. 
Johnston, Jack (1983) Econometric Methods. McGraw-Hill: New York.

Karrenbrok, Jeffrey D. (1991) "The Behavior of Retail Gasoline Prices: Symmetric or Not?” Federal Reserve Bank of St. Louis Review, 73: 19-29.

Katz, Michael L. (2001) "Network Effects, Interchange Fees, and No-Surcharge Rules in the Australian Credit and Charge Card Industry," Commissioned Report in Reform of Credit Card Schemes in Australia, Reserve Bank of Australia, August.

Katz, Michael L., and Harvey S. Rosen (1998) Microeconomics. Irwin/McGraw-Hill: Boston, Massachusetts.

Maxwell, Miranda (2005) "Tough Leader Wanted for Australia's Telstra," Reuters, May 10. http://www.reuters.com/newsArticle.jhtml?type=reutersEdge\&storyID $=8443245$

McKinnon, Michael (2001) “Credit Card Profit Under Fire,” Courier Mail, April 27.

Network Economics Consulting Group (2005) Early Evidence of the Impact of Reserve Bank of Australia Regulation of Open Credit Card Schemes. May.

Newmark, David, and Steven Sharpe (1992) "Market Structure and the Nature of Price Rigidity: Evidence from the Market for Consumer Deposits," Quarterly Journal of Economics, 107: 657-680.

Peltzman, Sam (2000) "Prices Rise Faster than they Fall," Journal of Political Economy, 108: 466-502.

Perron, Pierre (1989) "The Great Crash, the Oil Price Shock, and the Unit Root Hypothesis," Econometrica, 57: 1361-1401.

Poirier, Dale J. (1976) The Econometrics of Structural Change. North Holland: Amsterdam.

Poirier, Dale J. and Steven G. Garber (1974) "The Determinants of Aerospace Profit Rates 1951-1971," Southern Economic Journal, 41: 228-238.

Poterba, James (1999) "Retail Price Reactions to Changes in State and Local Sales Taxes," National Tax Journal, 49: 165-176.

RBA (2001) Reform of Credit Card Schemes in Australia I: A Consultation Document. December.

RBA (2002) Reform of Credit Card Schemes in Australia IV: Final Reforms and Regulation Impact Statement. August.

RBA (2004) Payment System Board Annual Report 2004.

RBA (2005a) Banking Fees in Australia.

RBA (2005b) Credit and Charge Card Statistics 
http://www.rba.gov.au/Statistics/Bulletin/C01hist.xls

RBA (2005c) Additional Credit Card Statistics

http://www.rba.gov.au/PaymentsSystem/PaymentsStatistics/ExcelFiles/RPS.xls

RBA (2005d) Market Shares Of Credit And Charge Card Schemes. http://www.rba.gov.au/Statistics/Bulletin/C02hist.xls

RBA and Australian Competition and Consumer Commission (2000) Debit and Credit Card Schemes in Australia: A Study of Interchange Fees and Access. October.

Rochet, Jean-Charles (2005) "The Interchange Fee Mysteries - Discussion of 'Economic Rationale for Interchange Fees' by D. Evans and R. Schmalensee," presented at a Conference Interchange Fees in Credit and Debit Card Industries: What Role for Public Authorities? Federal Reserve Bank of Kansas City, Santa Fe, New Mexico, May 4-6.

Rochet, Jean-Charles (2003) "The Theory of Interchange Fees: A Synthesis of Recent Contributions," Review of Network Economics, 2: 97-124.

Rochet, Jean-Charles and Jean Tirole (2002) "Cooperation among Competitors: Some Economics of Payment Card Associations," The RAND Journal of Economics, 33: 1-22.

Rochet, Jean-Charles and Jean Tirole (2003) "Platform Competition in Two-Sided Markets," Journal of the European Economic Association, 1: 990-1029.

Schmalensee, Richard (2002) "Payment Systems and Interchange Fees," Journal of Industrial Economics, 50: 103-122.

Schmalensee, Richard (2003) "Interchange Fees: A Review of the Literature," Payment Card Economics Review, 1: 25-44.

Stigler, George J., and James K. Kindahl (1970) The Behavior of Industrial Prices. National Bureau of Economic Research: New York.

Tyagi, Rajeev K. (1999) “A Characterization of Retailer Response to Manufacturer Trade Deals," Journal of Marketing Research, 36: 510-516.

Walters, Rockney G. (1989) “An Empirical Investigation into Retailer Response to Manufacturer Trade Promotions," Journal of Retailing, 65: 253-272.

Weiner, Stuart E. and Julian Wright (2005) "Interchange Fees in Various Countries: Developments and Determinants," Review of Network Economics, 4: 290-323

\section{$9 \quad$ Appendix A}

In order to determine whether issuers have made an attempt at recovering from cardholders some of the income lost due to the RBA regulation, we posed the question: In the period 
associated with the RBA regulation, is there evidence of a jump in the level of the card fees that issuers charge cardholders?

An examination of the Visa Australia series for other service charges per card and finance charges per card revealed that a few data points dramatically break the series trends. In the case of other service charges per card, the outliers are located in the second and third quarters of 1999 and the second quarter of 2000. In the case of finance charges per card, the outlier is located in the first quarter of 2004. To our knowledge, these are data problems rather than reflections of true change in the economic time series.

We took two different approaches in order to preclude our estimation from being driven by a few "influential" observations. First, we replaced the outliers with observations obtained via linear interpolation (Newton method). The results we report below were obtained on the basis of the interpolated data. Second, we kept the outliers in the dataset but ran robust regressions a la Huber (1964). In this iterative approach, observations receive weights that are a function of the magnitude of the associated residuals. For any given specification of the relevant model, the results obtained via robust regression were not substantially different from the ones obtained on the basis of the interpolated data.

\subsection{Fee levels}

In order to explore the question regarding the jump in fee levels in the regulatory period, we estimated a model of the following form:

$$
Y(t)=\alpha+\beta t+\gamma D(t)+\delta X(t)+\varepsilon(t)(A 1)
$$

In equation (A1), $\mathrm{Y}(\mathrm{t})$ is the level of the fees that issuers charge cardholders in each quarter, $t$ is a trend variable that takes on the value 1 at the starting point and grows by 1 each quarter, $\mathrm{D}(\mathrm{t})$ is a binary variable associated with the regulated period, and $\mathrm{X}(\mathrm{t})$ is a vector of other variables that may have had an impact on the level of $Y(t)$.

More specifically, we want to isolate the behaviour of issuers - therefore, we have to control for those elements of the behaviour of cardholders that could have had an impact on $\mathrm{Y}(\mathrm{t})$. For example, in a model where $\mathrm{Y}(\mathrm{t})$ is real other service charges per card (including annual fees and other usage fees) we may want to control for real purchase volume per card (in case there are elements of $\mathrm{Y}(\mathrm{t})$ that vary with the level of purchase activity). In a model where $\mathrm{Y}(\mathrm{t})$ is real finance charges per card we will certainly want to control for the level of real outstanding balances per card. The trend variable picks up the effect of unobservable factors that may have changed over time and may have exerted an influence upon $\mathrm{Y}(\mathrm{t})$. We also include binary variables for the second, third, and fourth quarters in order to control for potential seasonality in $\mathrm{Y}(\mathrm{t})$.

We estimated a number of different models to probe how robust our results were to various specifications. In some of these models we took into account the fact that real purchase volume per card and real outstanding balances per card may be endogenous - in other words, cardholders may choose the optimal level of these variables by taking into account the issuers' choice of fees and interest rates. In other words, we checked whether we obtained considerably different results with OLS vis-à-vis an instrumental-variable approach. For space reasons, we do not report the results of all the estimated models here. The results not reported were not substantially different from the ones reported and they are available from the authors upon request. 
In estimating models like (A1), researchers usually take two potential issues into account - the presence of serial correlation and the presence of stochastic trends. The results we report here were obtained by estimating the models with robust standard errors more specifically, Newey-West standard errors with four lags. We checked for the presence of stochastic trends by running Dickey-Fuller tests and co-integration tests on the relevant variables.

\subsubsection{Real other service charges per card}

We first estimated models where $\mathrm{Y}(\mathrm{t})$ is real other service charges per card per quarter. Other service charges include annual fees and other service fees, like over-limit and latepayment fees. A regression of $\mathrm{Y}(\mathrm{t})$ on a trend variable, binary quarterly variables, and a binary variable for the regulated period that takes on the value 1 starting in the first quarter of 2003 produced a coefficient on the regulation binary variable of 3.99 ( $p$-value $=$ 0.000). ${ }^{65}$ Augmented Dickey-Fuller tests on the residuals rejected the null of a unit root with up to one lag. It is unclear whether the failure to reject the null with more than one lag was due to the lack of power of the test (due to the small sample size) or not.

We added the real sale volume per card on the right hand side and the coefficient on the binary variable dropped to $3.50(\mathrm{p}$-value $=0.000) .{ }^{66}$ Augmented Dickey-Fuller tests on the residuals rejected the null (of no co-integration) with up to two lags. We then estimated a dynamic OLS (DOLS) model including the first difference of real sale volume per card on the right hand side, as well as one lag and one lead of the first difference. The coefficient on the binary variable dropped to 3.08 ( $p$-value $=0.000){ }^{67}$

We followed a similar procedure starting with a regression of $\mathrm{Y}(\mathrm{t})$ (other service charges per card) on the trend variable, quarterly binary variables, and a binary variable that takes on the value one for the first time in the first quarter of 2004. The coefficient on the binary variable was $3.72(\mathrm{p}$-value $=0.001) .{ }^{68} \mathrm{We}$ added real sale volume per card on the right hand side and the coefficient on the reform binary variable rose to 3.99 (p-value $=$ $0.000) .{ }^{69}$ We incorporated the first difference of real sale volume per card, and a lag and a

\footnotetext{
${ }^{65}$ For this model, the 4-lag Breusch-Godfrey test (that is, null hypothesis of no serial correlation) produced a p-value of 0.035 . Furthermore, a Prais-Winsten AR(1) regression produced a coefficient on the reform binary variable of 3.57 ( $\mathrm{p}$-value $=0.003)$.

${ }^{66}$ The Breusch-Godfrey test for this model produced a p-value of 0.114. Furthermore, a Prais-Winsten $\mathrm{AR}(1)$ regression produced a coefficient on the reform binary variable of 3.56 ( $\mathrm{p}$-value $=0.002$ ).

${ }^{67}$ The Breusch-Godfrey test for this model produced a p-value of 0.030 . A Prais-Winsten AR(1) regression produced a coefficient on the binary variable of $2.74(\mathrm{p}$-value $=0.02)$. After incorporating only the $3^{\text {rd }}$ lag of real sale volume per card on the right hand side, the model produced a coefficient on the reform binary variable of 2.83 ( $p$-value $=0.008)$, and the Breusch-Godfrey test yielded a p-value of 0.114 . After incorporating only the $4^{\text {th }}$ lag we obtained a coefficient on the reform binary variable of 3.09 ( $p$-value $=$ 0.001 ) and a Breusch-Godfrey p-value of 0.341 . With the $3^{\text {rd }}$ and the $4^{\text {th }}$ lags in the model we obtained a coefficient on the reform binary variable of 2.89 ( $p$-value $=0.005$ ) and a Breusch-Godfrey p-value of 0.209. Incorporating the real 30-day interest rate on the right hand side (in the model without the lagged real-salevolume-per-card variables) generated an estimated coefficient of 3.18 ( $\mathrm{p}$-value $=0.002$ ) for the reform binary variable.

${ }^{68}$ The Breusch-Godfrey test produced a p-value of 0.0003 . A Prais-Winsten AR(1) regression produced a coefficient on the reform binary variable of 3.15 ( $p$-value $=0.036)$.

${ }^{69}$ The Breusch-Godfrey test produced a p-value of 0.003. A Prais-Winsten AR(1) regression produced a coefficient on the reform binary variable of $3.62(p$-value $=0.016)$.
} 
lead of the first difference, and obtained a coefficient on the binary variable of 4.11 ( $\mathrm{p}$ value $=0.001)^{70}$

\subsubsection{Consistency with RBA data}

Our analysis based on quarterly Visa data is also broadly consistent with two separate sources of data on fees reported on an annual basis by the RBA. ${ }^{71}$ The first source is total fee income (not including finance charges) received by banks on all credit cards. This series tracks closely to the Visa data. For example, average fee income per card in 2001 was AU\$31.19 from the RBA data and AU\$29.67 from the Visa data, and was AU\$52.03 in 2003 from the RBA data and AU\$52.45 from the Visa data. The increase from 2001 to 2003 was AU\$20.84 from the RBA data and AU\$22.78 from the Visa data.

The RBA also reports survey data on average fees for cards with interest-free periods and rewards programs issued by major banks. From 2002 to 2004, fees increased significantly: from $\$ 61$ to $\$ 85$ for annual fees on standard cards; from $\$ 98$ to $\$ 128$ for annual fees on gold cards; from $\$ 21$ to $\$ 29$ for late payment fees; and from $\$ 13$ to $\$ 29$ for over-limit fees. Thus, taking annual fees alone, for cards in this survey, fees increased by $\$ 24$ a year for standard cards and \$30 for gold cards. If we include one late fee and one over-limit fee penalty per year, total fees increased by $\$ 48$ a year for standard cards and $\$ 54$ a year for gold cards.

There are at least two reasons why these survey data on rewards cards indicate higher fee increases than the calculations we have reported based on the aggregate data (leaving aside the fact that the limited annual data series do no allow for full controls). First, cardholder spending is higher on rewards cards, so the loss in interchange fee income is greater. Second, replacing existing cardholders with new ones is costly and banks may be reluctant to raise fees as much to existing cardholders as to new cardholders.

\subsubsection{Real finance charges per card}

We followed the same approach with $\mathrm{Y}(\mathrm{t})$ defined as real finance charges per card. So, for example, a regression of real finance charges per card on a trend variable, a binary variable for the regulated period starting in 2003, and quarterly binary variables, produced a coefficient for the regulated period of $7.72(\mathrm{p}$-value $=0.002) .{ }^{72}$ Dickey-Fuller tests did not reject the null of a unit root. After adding real outstanding balances per card on the right hand side, the coefficient for the regulated period dropped to $2.16(\mathrm{p}$-value $=0.167){ }^{73}$

\footnotetext{
${ }^{70}$ The Breusch-Godfrey test for this model produced a p-value of 0.0001 . A Prais-Winsten AR(1) regression produced a coefficient on the binary variable of 3.94 ( $\mathrm{p}$-value $=0.012$ ). After incorporating only the $3^{\text {rd }}$ lag of real sale volume per card on the right hand side, we obtained a coefficient on the reform binary variable of $4.75(\mathrm{p}$-value $=0.001)$ and a Breusch-Godfrey p-value of 0.0004 . After incorporating only the $4^{\text {th }}$ lag, we obtained a coefficient on the reform binary variable of $5.40(p$-value $=0.001)$ and a Breusch-Godfrey $p$ value of 0.005 . After incorporating both the $3^{\text {rd }}$ and $4^{\text {th }}$ lags, we obtained a coefficient on the reform variable of 5.19 (p-value $=0.001)$ and a Breusch-Godfrey p-value of 0.003 . On the other hand, a model that incorporated four lags of real other service charges per card on the right hand side produced a coefficient on the reform binary variable of $3.78(p$-value $=0.000)$ and a Breusch-Godfrey p-value of 0.243 . Incorporating the real 30-day interest rate on the right hand side (in the model without the lagged variables) generated an estimated coefficient of $3.90(p$-value $=0.001)$ for the reform binary variable.

${ }^{71}$ See RBA (2005a)

72 The Breusch-Godfrey test produced a p-value of 0.000. A Prais-Winsten AR(1) regression produced a coefficient on the reform binary variable of -0.098 ( $p$-value $=0.940)$.

${ }^{73}$ The Breusch-Godfrey p-value for this model was 0.000. A Prais-Winsten AR(1) regression produced a coefficient on the reform binary variable of $1.01(\mathrm{p}$-value $=0.389)$.
} 
Augmented Dickey-Fuller tests rejected the null of no co-integration with two, three, and four lags. We estimated a DOLS model adding the first difference of real outstanding balances per card, and a lag and a lead of the first difference, and obtained a coefficient on the regulated period of $1.88(\mathrm{p}$-value $=0.242) .^{74}$

We followed the same approach starting with a regression of real finance charges per card on a trend variable, a binary variable for the regulated period starting in 2004, and quarterly binary variables. We obtained a coefficient on the regulation variable of 6.65 (pvalue $=0.05) .^{75}$ The reform variable coefficient dropped to $1.89(\mathrm{p}$-value $=0.047)$ after controlling for changes in real outstanding balances per card. ${ }^{76}$ After adding the first difference of real outstanding balances per card, and a lag and a lead of the first difference, we obtained a coefficient on the regulated period of $1.14(\mathrm{p}$-value $=0.316){ }^{77}$

\subsubsection{Summary on fee levels}

In summary, the evidence suggests that there was a jump in real other service charges per card associated with the RBA regulation. Depending on when we believe the structural break happened, the magnitude of the jump may have been roughly between AU $\$ 3$ and AU\$4 per quarter. The evidence of a jump in real finance charges per card is not as strong - the coefficients are much more sensitive to model specification and are, for the most part, not significant at standard confidence levels after controlling for changes in real outstanding balances per card.

\footnotetext{
${ }^{74}$ The Breusch-Godfrey p-value for this model was 0.000. A Prais-Winsten AR(1) regression produced a coefficient on the reform binary variable of 0.23 ( $\mathrm{p}$-value $=0.868$ ). The Breusch-Godfrey test continued to reject the null of no serial correlation even after adding lags of real outstanding balances per card and real finance charges per card on the right hand side. Incorporating a measure of the opportunity cost of funds on the right hand side (in the model without the lagged variables) generated an estimated coefficient of 1.78 (pvalue $=0.287$ ) for the reform binary variable.

${ }^{75}$ The Breusch-Godfrey p-value for this model was 0.000. Furthermore, a Prais-Winsten AR(1) regression produced a coefficient on the reform binary variable of 0.798 ( $\mathrm{p}$-value $=0.542$ ).

${ }^{76}$ The Breusch-Godfrey p-value for this model was 0.000. A Prais-Winsten AR(1) regression produced a coefficient on the reform binary variable of 2.50 ( $p$-value $=0.033$ ).

${ }^{77}$ The Breusch-Godfrey $p$-value for this model was 0.000 . A Prais-Winsten AR(1) regression produced a coefficient on the reform binary variable of 2.15 ( $\mathrm{p}$-value $=0.131$ ). The Breusch-Godfrey test continued to reject the null of no serial correlation even after incorporating lags of real outstanding balances per card and real finance charges per card. Incorporating a measure of the opportunity cost of funds on the right hand side (in the model without the lagged variables) generated an estimated coefficient of 1.25 (p-value $=0.257$ ) for the reform binary variable.
} 